\title{
Serum lipid profile of broilers fed diets with inclusion of mango waste meal
}

\section{Perfil lipídico sérico de frangos de corte alimentados com inclusão de farelo de resíduo de manga nas rações}

\author{
Patrícia Aparecida Fontes Vieira ${ }^{1 *}$; Christiane Silva Souza ${ }^{2}$; \\ Anderson de Almeida Barbosa ${ }^{3}$; Heder José D’Ávila Lima ${ }^{4}$; \\ Edimar Aparecida Filomeno Fontes ${ }^{5}$; Breno César Vieira ${ }^{6}$; \\ Maria Goreti de Almeida Oliveira ${ }^{7}$; George Henrique Kling de Moraes ${ }^{7}$; \\ José Humberto de Queiroz ${ }^{7}$; Luiz Fernando Teixeira Albino ${ }^{8}$
}

\begin{abstract}
We evaluated the effect of including 2.5, 5.0, 7.5 and 10.0\% mango waste meal (MWM) variety UBA in corn and soybean meal-based diet on the serum lipid profile of broilers. The experimental design was completely randomized, with five treatments and six replicates with 20 birds per experimental unit. Concentrations of creatinine, albumin, total protein, total cholesterol, triacylglycerols (TAG), high-density lipoprotein cholesterol (HDL-C), low-density lipoprotein cholesterol (LDL-C) and very-low-density lipoprotein cholesterol (VLDL-C), were evaluated at the ages of 14, 28 and 42 days, with 30 birds evaluated per age. At 14 days, there was no difference serum creatinine, total cholesterol, HDL, triacylglycerols, total proteins or VLDL-C concentrations as compared with control. Albumin concentration was the highest at the MWM inclusion levels of 5.0, 7.5 and 10.0\%. At 28 days, triacylglycerols, VLDL-C and LDL-C were the lowestat $7.5 \%$ inclusion whereas at 42 days, these same variables were the lowest with addition of $10.0 \%$ meal. At 14, 28 and 42 days of age, the VLDL-C, LDL-C and total TAG contents were found to decrease at mango waste meal inclusion levels of 5.0 and $7.5 \%$ in the diets, which maybe considered an indicator of improvements in the metabolic conditions of broilers.
\end{abstract}

Key words: Lipid analysis. Poultry farming. Mangifera indica L. Triacylglycerol.

\section{Resumo}

Avaliou-se o efeito da inclusão de 2,5; 5,0; 7,5 e 10,0\% do farelo do resíduo de manga (FRM) variedade Ubá em dietas à base de milho e farelo de soja sobre o perfil lipídico sérico de frangos de corte. $\mathrm{O}$

\footnotetext{
${ }^{1}$ Prof. Adjunto, Departamento de Nutrição, Universidade Federal de Juiz de Fora, UFJF, Juiz de Fora, MG, Brasil. E-mail: papfontes@yahoo.com.br

2 Zootecnista, Dr ${ }^{\mathrm{a}}$ em Bioquímica Aplicada, Universidade Federal de Viçosa, UFV, Viçosa, MG, Brasil. E-mail: christiane_s_ souza@hotmail.com

3 Médico Veterinário, Dr. em Bioquímica Agrícola, UFV, Viçosa, MG, Brasil. E-mail: aab62@hotmail.com

${ }^{4}$ Prof. Adjunto, Departamento de Zootecnia, Universidade Federal de Mato Grosso, UFMT, Cuiabá, MT, Brasil. E-mail: hederdavila@yahoo.com.br

5 Prof. Adjunto, Departamento de Tecnologia de Alimentos, DTA/UFV, Viçosa, MG, Brasil. E-mail: eaffontes@ufv.br

${ }^{6}$ Prof., Instituto Federal Sudeste de Minas Gerais, IF Sudeste, Barbacena, MG; Discente do Curso de Doutorado do Programa de Pós-Graduação em Bioquímica Aplicada, Departamento de Bioquímica e Biologia Molecular, DBB/UFV, Viçosa, MG, Brasil. E-mail: breno.vieira@ufv.br

7 Profs. Titular, DBB/UFV, Viçosa, MG, Brasil. E-mail: ghkmoraes@gmail.com; jqueiroz@ufv.br; mgoalmeida@gmail.com

${ }^{8}$ Prof. Titular, Departamento de Zootecnia, UFV, Viçosa, MG, Brasil. E-mail: lalbino@ufv.br

* Author for correspondence
} 
delineamento foi inteiramente casualizado, sendo cinco tratamentos com seis repetições de 20 aves por unidade experimental. Avaliaram-se as concentrações de creatinina, albumina, proteínas totais, colesterol total, triacilglicerois (TAG), lipoproteínas de alta densidade (HDL), lipoproteínas de baixa densidade (LDL), lipoproteínas de densidade de muito baixa (VLDL) nas idades de 14, 28 e 42 dias, sendo avaliadas 30 aves por idade. Aos 14 dias não houve diferença nas concentrações séricas de creatinina, colesterol total, HDL, triacilglicerois, proteínas totais e VLDL quando comparados com o controle. A concentração de albumina foi superior para os níveis de inclusão de 5,0; 7,5 e 10,0\% de FRM. Aos 28dias, triacilglicerois, VLDL e LDL foram menores em 7,5\% de inclusão, enquanto que aos 42 dias, essas mesmas variáveis foram menores com a adição de 10,0\%. Aos 14, 28 e 42dias de idade foram observadas reduções dos teores de VLDL, LDL e TAG totais nos níveis de inclusão de FRM de 5,0\% e 7,5\% nas rações, isso pode ser considerado como indicador na melhoria das condições metabólicas dos frangos de corte.

Palavras-chave: Avicultura. Lipidograma. Mangifera indica L. Triacilglicerol.

\section{Introduction}

Industrial poultry farming is an important segment of Brazilian agribusiness that generates jobs and income for populations of different regions. The production costs, mainly those related to feeding in this supply chain, are the most expensive, accounting for approximately $70.0 \%$ of the total expenditures. Soybean meal and corn are the most widely used ingredients in poultry diets; thus, the availability and prices of these raw materials have a direct influence on the costs of diets (VIEITES et al., 2014).

Many research studies on the use of alternative sources as substitutes for corn and soybean in diets have been conducted with the aim of making production economically feasible. In addition to the aforementioned fact, another noteworthy aspect is the environmental sustainability of the productive process. The poultry industry has sought alternative nutritional sources that allow for equating costs and environmental conditions. Among these sources are the agribusiness wastes originating from the production of fruit juice and fruit pulp (GERON et al., 2013).

Regarding the use of by-products in broiler diets, those of fruits such as cashew pulp and mango waste meal have been studied and the results show that animal performance and carcass and cut yields were not compromised, which indicates the possibility of their use in the feeding of these birds (RAMOS et al., 2006; VIEIRA et al., 2008).
Mango waste is an alternative because the peels and seeds have appreciable amounts of unsaturated fatty acids (UFA), phenolic compounds, vitamins $\mathrm{C}$ and $\mathrm{E}$, antioxidants and reducers of plasma triacylglycerols (TAG) levels when added to diets (ABDALLA et al., 2007; AJILA et al., 2007; FREITAS et al., 2012; HUBER et al., 2012).

In addition to the paramount contribution of genetic breeding, success in poultry farming is a result of nutrition. Average daily weight gain increased from 20 to over $50 \mathrm{~g} \mathrm{day}^{-1}$, and the slaughter age of birds was reduced from 12 to 6 weeks (PONSO et al., 2012). As the slaughter age was reduced, some metabolic disorders related to the levels of TAG and plasma lipoproteins, which are linked to sudden death and ascites syndromes, were detected (SQUIRES; SUMMERS, 1993). Hence, ingredients that allow for reductions in TAG and cholesterol levels have been tested in broiler diets (TOGASHI et al., 2008).

The objective was to measure total cholesterol and its fractions in the blood serum of broilers fed diets with inclusion of mango waste meal.

\section{Material and Methods}

The experiment was conducted on the Poultry Breeding Farm at the Department of Animal Science of Universidade Federal de Viçosa (UFV). Six hundred (600) 1-day-old male Ross ${ }^{\circledR}$ chicks with an average initial weight of $43.0 \mathrm{~g}$ were distributed in a completely randomized design with five treatments 
$\left(\mathrm{T}_{1}-0.0 ; \mathrm{T}_{2}-2.5 ; \mathrm{T}_{3}-5.0 ; \mathrm{T}_{4}-7.5\right.$ and $\mathrm{T}_{5}-10.0 \%$ mango waste meal [MWM] in the diets) and six replicates with 20 birds in each.

The MWM consisted of peels, seeds and defective ripe fruits obtained from a juice industry located in the municipality of Ubá - MG, Brazil. The material was dried at $60{ }^{\circ} \mathrm{C}$ in a ventilated oven for $72 \mathrm{~h}$ and ground in a mill ( $3 \mathrm{~mm}$ sieve) to obtain the MWM. The composition of the MWM (expressed on a dry matter basis) was as follows: $92.23 \%$ dry matter, $3.87 \%$ crude protein, $37.25 \%$ neutral detergent fibre, $21.84 \%$ acid detergent fibre, $14.60 \%$ crude fibre, $4.36 \%$ ether extract, $2.08 \%$ mineral matter, $0.18 \%$ calcium, $0.11 \%$ phosphorus, $81.92 \%$ total carbohydrates, $390.60 \mathrm{kcal}$ gross energy (per $100 \mathrm{~g}$ meal) and $5.80 \mathrm{~g}$ total phenols (gallic acid equivalents (GAE) per $100 \mathrm{~g}$ of meal) (VIEIRA et al., 2008).

The diets were formulated by following the Rostagno et al. (2005) recommendations for the different broiler rearing phases ( 1 to 21 and 22 to 42 days of age). The composition of the experimental diets is described in Table 1 .

Table 1. Composition of the experimental diets supplied to the broilers in the starter ( 1 to 21 days) and finisher (22 to 42 days) phases.

\begin{tabular}{|c|c|c|c|c|c|c|c|c|c|c|}
\hline \multirow[b]{3}{*}{ Ingredients } & \multicolumn{10}{|c|}{ MWM inclusion levels (\%) } \\
\hline & \multicolumn{5}{|c|}{1 to 21 days } & \multicolumn{5}{|c|}{22 to 42 days } \\
\hline & 0.0 & 2.5 & 5.0 & 7.5 & 10.0 & 0.0 & 2.5 & 5.0 & 7.5 & 10.0 \\
\hline Corn & 60.110 & 56.350 & 52.590 & 48.830 & 45.070 & 65.170 & 61.380 & 57.590 & 53.790 & 50.000 \\
\hline Soybean meal & 34.689 & 35.120 & 35.540 & 35.970 & 36.400 & 28.550 & 29.020 & 29.490 & 29.960 & 30.430 \\
\hline Mango waste meal & 0.000 & 2.500 & 5.000 & 7.500 & 10.000 & 0.000 & 2.500 & 5.000 & 7.500 & 10.000 \\
\hline Dicalcium phosphate & 1.815 & 1.820 & 1.830 & 1.830 & 1.840 & 1.585 & 2.280 & 2.060 & 1.830 & 1.610 \\
\hline Soybean oil & 1.180 & 2.020 & 2.850 & 3.690 & 4.520 & 2.500 & 2.640 & 3.700 & 4.760 & 5.820 \\
\hline Limestone (38\%) & 0.889 & 0.870 & 0.860 & 0.840 & 0.820 & 0.820 & 0.800 & 0.790 & 0.770 & 0.760 \\
\hline Salt & 0.494 & 0.500 & 0.500 & 0.500 & 0.500 & 0.457 & 0.460 & 0.460 & 0.460 & 0.460 \\
\hline DL-methio & 0.253 & 0.260 & 0.270 & 0.280 & 0.280 & 0.238 & 0.250 & 0.250 & 0.260 & 0.270 \\
\hline L-lysine $\mathrm{HCl}(9$ & 0.204 & 0.200 & 0.200 & 0.190 & 0.190 & 0.290 & 0.280 & 0.270 & 0.260 & 0.250 \\
\hline L-thre & 0.056 & 0.060 & 0.060 & 0.070 & 0.070 & 0.080 & 0.080 & 0.090 & 0.090 & 0.090 \\
\hline Minera & 0.050 & 0.050 & 0.050 & 0.050 & 0.050 & 0.050 & 0.050 & 0.050 & 0.050 & 0.050 \\
\hline vitam & 0.100 & 0.100 & 0.100 & 0.100 & 0.100 & 0.100 & 0.100 & 0.100 & 0.100 & 0.100 \\
\hline Anticoccidial $^{3}$ & 0.050 & 0.050 & 0.050 & 0.050 & 0.050 & 0.050 & 0.050 & 0.050 & 0.050 & 0.050 \\
\hline loride $(60 \%)$ & 0.100 & 0.100 & 0.100 & 0.100 & 0.100 & 0.100 & 0.100 & 0.100 & 0.100 & 0.100 \\
\hline Antioxidant (BHT) & 0.010 & 0.010 & 0.010 & 0.010 & 0.010 & 0.010 & 0.010 & 0.010 & 0.010 & 0.010 \\
\hline & 100.00 & 100.00 & 100.00 & 100.00 & 100.00 & 100.00 & 100.00 & 100.00 & 100.00 & 100.00 \\
\hline \multicolumn{11}{|c|}{ Calculated composition } \\
\hline Metabolizable energ & 2.950 & 2.950 & 2.950 & 2.950 & 2.950 & 3.099 & 3.099 & 3.099 & 3.099 & 3.099 \\
\hline Crude protein $(\%)$ & 21.000 & 21.000 & 21.000 & 21.000 & 21.000 & 18.700 & 18.700 & 18.700 & 18.700 & 18.700 \\
\hline Calcium (\%) & 0.893 & 0.890 & 0.890 & 0.890 & 0.890 & 0.796 & 0.790 & 0.790 & 0.780 & 0.776 \\
\hline Available phosphorus (\%) & 0.446 & 0.450 & 0.450 & 0.450 & 0.450 & 0.397 & 0.400 & 0.400 & 0.400 & 0.397 \\
\hline Sodium $(\%)$ & 0.215 & 0.220 & 0.210 & 0.210 & 0.210 & 0.200 & 0.200 & 0.200 & 0.200 & 0.200 \\
\hline Digestible lysine (\%) & 1.172 & 1.170 & 1.170 & 1.170 & 1.170 & 1.093 & 1.090 & 1.090 & 1.080 & 1.077 \\
\hline Digestible methionine (\%) & 0.546 & 0.550 & 0.550 & 0.560 & 0.560 & 0.504 & 0.510 & 0.510 & 0.520 & 0.520 \\
\hline Digestible threonine (\%) & 0.761 & 0.760 & 0.760 & 0.760 & 0.760 & 0.700 & 0.700 & 0.700 & 0.700 & 0.700 \\
\hline Crude fiber $(\%)$ & 2.917 & 3.240 & 3.560 & 3.890 & 4.210 & 2.672 & 2.980 & 3.290 & 3.600 & 3.911 \\
\hline
\end{tabular}

${ }^{1}$ Mineral supplement $\left(\right.$ Roche $^{\circledR}$ ), guaranteed levels per kg: Mn - 16 g; Fe - 100 g; Zn - 100 g; Cu - 20 g; Co - 2.0 g; I - 2 g; excipient q.s. - 1,000 g. ${ }^{2}$ Vitamin supplement $\left(\right.$ Roche $\left.^{\circledR}\right)$, guaranteed levels per kg: vit. A - 10,000,000 IU, vit. $\mathrm{D}_{3}$ - 2,000,000 IU; vit. E - 30,000 IU; vit. $\mathrm{B}_{1}$ - 2g; vit.B -4 g; pantothenic acid - 12 g; biotin - 0.10 g; vit. $\mathrm{K}_{3}-3 \mathrm{~g}$; folic acid - $1 \mathrm{~g}$; nicotinic acid - 50 g; vit. $\mathrm{B}_{12}$ - 15,000 mcg; Se - $0.25 \mathrm{~g}$; excipient q.s. - 1,000 g. ${ }^{3}$ Coxistac $^{\circledR} 12 \%$. 
Chicks were housed in a masonry shed divided into thirty $1.5 \times 2.0 \mathrm{~m}$ pens. The poultry litter was made of wood shavings. The adopted lighting program was continuous (natural + artificial light), and feed and water were supplied ad libitum throughout the entire experimental period.

Ninety (90) birds were used to determine serum lipid profile components, corresponding to 30 birds per age (14, 28 and 42 days). Blood samples obtained after the animals were euthanized by cervical dislocation and jugular venipuncture were centrifuged at $3000 \mathrm{rpm}$ for $15 \mathrm{~min}$ to separate the serum and kept at $-20{ }^{\circ} \mathrm{C}$ for subsequent biochemical analyses.

Serological measurements of creatinine, total cholesterol, high-density lipoprotein cholesterol
(HDL-C), low-density lipoprotein cholesterol (LDL-C), very-low-density lipoprotein cholesterol (VLDL-C), triacylglycerols (TAG) and albumin were performed in a multiparametric biochemistry device $\left(\right.$ Allizé $\left.^{\circledR}\right)$. The data were analyzed using the Statistical Analysis System (SAS, 2001) software, with means subjected to analysis of variance and compared by Dunnett's test at a 5\% level of significance.

\section{Results and Discussion}

At 14 days of age (Table 2), serum concentrations of creatinine, total protein, triacylglycerols, cholesterol and its fractions did not differ among the broilers fed diets containing MWM.

Table 2. Blood concentrations of total cholesterol, HDL, TAG, VLDL, LDL, creatinine, albumin and total proteins in broilers at 14 days of age.

\begin{tabular}{|c|c|c|c|c|c|c|c|c|}
\hline $\begin{array}{l}\% \text { MWMin } \\
\text { the diets }\end{array}$ & $\begin{array}{c}\text { Total } \\
\text { cholesterol } \\
\left(\mathrm{mg} \mathrm{dL}^{-1}\right)\end{array}$ & $\begin{array}{c}\text { HDL } \\
\left(\mathrm{mg} \mathrm{dL}^{-1}\right)\end{array}$ & $\begin{array}{c}\text { TAG } \\
\left(\mathrm{mg} \mathrm{dL}^{-1}\right)\end{array}$ & $\begin{array}{c}\text { VLDL } \\
\left(\mathrm{mg} \mathrm{dL}^{-1}\right)\end{array}$ & $\begin{array}{c}\text { LDL } \\
\left(\mathrm{mg} \mathrm{dL}^{-1}\right)\end{array}$ & $\begin{array}{c}\text { Creatinine } \\
\left(\mathrm{mg} \mathrm{dL}^{-1}\right)\end{array}$ & $\begin{array}{c}\text { Albumin } \\
\left(\mathrm{g} \mathrm{dL}^{-1}\right)\end{array}$ & $\begin{array}{c}\text { Total } \\
\text { proteins } \\
\left(\mathrm{g} \mathrm{L}^{-1}\right)\end{array}$ \\
\hline $\mathrm{T} 1-0.0 \%$ & $153.417^{\mathrm{ns}}$ & 92.967 & 47.550 & 9.510 & 50.940 & 0.358 & 1.568 & 25.684 \\
\hline $\mathrm{T} 2-2.5 \%$ & $159.275^{\mathrm{ns}}$ & $95.833^{\mathrm{ns}}$ & $56.783^{\mathrm{ns}}$ & $11.357^{\mathrm{ns}}$ & $52.085^{\mathrm{ns}}$ & $0.373^{\mathrm{ns}}$ & $1.699^{\mathrm{ns}}$ & $29.832^{\text {ns }}$ \\
\hline $\mathrm{T} 3-5.0 \%$ & $151.442^{\mathrm{ns}}$ & $102.017^{\mathrm{ns}}$ & $37.717^{\mathrm{ns}}$ & $7.543^{\mathrm{ns}}$ & $41.882^{\mathrm{ns}}$ & $0.395^{\text {ns }}$ & $1.833^{*}$ & $29.849^{\mathrm{ns}}$ \\
\hline $\mathrm{T} 4-7.5 \%$ & $142.600^{\mathrm{ns}}$ & $95.200^{\mathrm{ns}}$ & $32.050^{\mathrm{ns}}$ & $6.410^{\mathrm{ns}}$ & $40.990^{\mathrm{ns}}$ & $0.388^{\text {ns }}$ & $1.826^{*}$ & $29.843^{\mathrm{ns}}$ \\
\hline T5 - $10 \%$ & $137.750^{\mathrm{ns}}$ & $92.200^{\mathrm{ns}}$ & $33.850^{\mathrm{ns}}$ & $6.770^{\text {ns }}$ & $38.780^{*}$ & $0.370^{\text {ns }}$ & $1.952^{*}$ & $28.123^{\mathrm{ns}}$ \\
\hline LSD & 21.432 & 16.396 & 19.923 & 3.985 & 10.217 & 0.0884 & 0.1958 & 4.669 \\
\hline CV (\%) & 9.563 & 11.390 & 31.827 & 31.827 & 15.107 & 15.578 & 7.326 & 10.821 \\
\hline
\end{tabular}

LSD: least significant difference. ${ }^{\text {ns: }}$ not significant at the level of $5 \%$ probability by Dunnett's test; * significant at the level of 5\% probability by Dunnett's test. CV: coefficient of variation.

There was a lower concentration of LDL-C in the serum of birds fed the diet with the highest inclusion of MWM as compared with those that received the control diet. The chicks fed diets with levels equal to or higher than 5\% MWM showed a greater albumin level. However, the obtained results, $1.568 \mathrm{~g} \mathrm{dL}^{-1}$ to $1.952 \mathrm{~g} \mathrm{dL}^{-1}$, were within the normal range, and this outcome was similar to the 1.54 to $1.9 \mathrm{~g} \mathrm{dL}^{-1}$ found by González et al. (2001).

At 28 days of age (Table 3), creatinine, total cholesterol, HDL and albumin were not affected by the addition of MWM to the diets. Total cholesterol and albumin conformed to the values mentioned by González et al. (2001), which were 95.6 to 131.2 $\mathrm{mg} \mathrm{dL}^{-1}$ and 1.43 to $1.87 \mathrm{~g} \mathrm{dL}^{-1}$, respectively. The 
total protein content in the plasma of the birds was lower at the level of $10.0 \%$ of inclusion of MWM in the diets as compared with the control treatment.
Nevertheless, it was within the normality range, from 27.1 to $39.6 \mathrm{~g} \mathrm{~L}^{-1}$ (MACARI; LUQUETTI, 2002).

Table 3. Blood concentrations of total cholesterol, HDL, TAG, VLDL, LDL, creatinine, albumin and total proteins in broilers at 28 days of age.

\begin{tabular}{|c|c|c|c|c|c|c|c|c|}
\hline $\begin{array}{l}\% \text { MWM in } \\
\text { the diets }\end{array}$ & $\begin{array}{c}\text { Total } \\
\text { cholesterol } \\
\left(\mathrm{mg} \mathrm{dL}^{-1}\right)\end{array}$ & $\begin{array}{c}\text { HDL } \\
\left(\mathrm{mg} \mathrm{dL}^{-1}\right)\end{array}$ & $\begin{array}{c}\text { TAG } \\
\left(\mathrm{mg} \mathrm{dL}^{-1}\right)\end{array}$ & $\begin{array}{c}\text { VLDL } \\
\left(\mathrm{mg} \mathrm{dL}^{-1}\right)\end{array}$ & $\begin{array}{c}\text { LDL } \\
\left(\mathrm{mg} \mathrm{dL}^{-1}\right)\end{array}$ & $\begin{array}{c}\text { Creatinine } \\
\left(\mathrm{mg} \mathrm{dL}^{-1}\right)\end{array}$ & $\begin{array}{c}\text { Albumin } \\
\left(\mathrm{g} \mathrm{dL}^{-1}\right)\end{array}$ & $\begin{array}{c}\text { Total } \\
\text { proteins } \\
\left(\mathrm{g} \mathrm{L}^{-1}\right)\end{array}$ \\
\hline $\mathrm{T} 1-0.0 \%$ & 118.267 & 77.483 & 38.542 & 7.708 & 33.075 & 0.253 & 1.750 & 33.880 \\
\hline $\mathrm{T} 2-2.5 \%$ & $112.992^{\mathrm{ns}}$ & $78.667^{\mathrm{ns}}$ & $36.367^{\mathrm{ns}}$ & $7.273^{\mathrm{ns}}$ & $27.052^{\mathrm{ns}}$ & $0.263^{\mathrm{ns}}$ & $1.728^{\mathrm{ns}}$ & $31.273^{\mathrm{ns}}$ \\
\hline $\mathrm{T} 3-5.0 \%$ & $112.325^{\mathrm{ns}}$ & $80.283^{\text {ns }}$ & $31.842^{\mathrm{ns}}$ & $6.368^{\mathrm{ns}}$ & $25.673^{\text {ns }}$ & $0.273^{\mathrm{ns}}$ & $1.793^{\mathrm{ns}}$ & $29.318^{\mathrm{ns}}$ \\
\hline $\mathrm{T} 4-7.5 \%$ & $100.967^{\mathrm{ns}}$ & $74.817^{\mathrm{ns}}$ & $23.033^{*}$ & $4.607^{*}$ & $21.543^{*}$ & $0.259^{\mathrm{ns}}$ & $1.822^{\mathrm{ns}}$ & $31.488^{\mathrm{ns}}$ \\
\hline T5 $-10 \%$ & $115.333^{\mathrm{ns}}$ & $83.783^{\text {ns }}$ & $26.283^{\text {ns }}$ & $5.257^{\mathrm{ns}}$ & $26.293^{\mathrm{ns}}$ & $0.227^{\mathrm{ns}}$ & $1.868^{\mathrm{ns}}$ & $27.743^{*}$ \\
\hline LSD & 19.906 & 16.732 & 13.055 & 2.611 & 11.000 & 0.075 & 0.1605 & 5.3618 \\
\hline $\mathrm{CV}(\%)$ & 11.811 & 14.071 & 27.789 & 27.789 & 27.343 & 19.552 & 5.951 & 11.588 \\
\hline
\end{tabular}

LSD: least significant difference. ${ }^{\text {ns: }}$ not significant at the level of $5 \%$ probability by Dunnett's test; * significant at the level of $5 \%$ probability by Dunnett's test. CV: coefficient of variation.

At 42 days of age (Table 4), albumin concentrations were the highest with the addition of $7.5 \%$ and $10.0 \%$ MWM to the diets. Hasegawa et al. (2002) found values that ranged from 0.9 to $2.1 \mathrm{~g}$
$\mathrm{dL}^{-1}$ for birds of the Avian Farm line. In the present study, it was observed that the increase in albumin concentration was not capable of influencing the total protein content $(P>0.05)$.

Table 4. Blood concentrations of total cholesterol, HDL, TAG, VLDL, LDL, creatinine, albumin and total proteins in broilers at 42 days of age.

\begin{tabular}{|c|c|c|c|c|c|c|c|c|}
\hline $\begin{array}{l}\% \text { MWM in } \\
\text { the diets }\end{array}$ & $\begin{array}{c}\text { Total } \\
\text { cholesterol } \\
\left(\mathrm{mg} \mathrm{dL}^{-1}\right)\end{array}$ & $\begin{array}{c}\text { HDL } \\
\left(\mathrm{mg} \mathrm{dL}^{-1}\right)\end{array}$ & $\begin{array}{c}\text { TAG } \\
\left(\mathrm{mg} \mathrm{dL}^{-1}\right)\end{array}$ & $\begin{array}{c}\text { VLDL } \\
\left(\mathbf{m g ~ d L}^{-1}\right)\end{array}$ & $\begin{array}{c}\text { LDL } \\
\left(\mathrm{mg} \mathrm{dL}^{-1}\right)\end{array}$ & $\begin{array}{c}\text { Creatinine } \\
\left(\mathrm{mg} \mathrm{dL}^{-1}\right)\end{array}$ & $\begin{array}{l}\text { Albumin } \\
\left(\mathrm{g} \mathrm{dL}^{-1}\right)\end{array}$ & $\begin{array}{c}\text { Total } \\
\text { proteins } \\
\left(g^{-1} \mathbf{L}^{-1}\right.\end{array}$ \\
\hline $\mathrm{T} 1-0.0 \%$ & 125.633 & 80.058 & 52.233 & 10.447 & 35.128 & 0.305 & 1.869 & 36.860 \\
\hline $\mathrm{T} 2-2.5 \%$ & $122.317^{\mathrm{ns}}$ & $79.750^{\text {ns }}$ & $42.697^{\mathrm{ns}}$ & $8.538^{\mathrm{ns}}$ & $34.028^{\mathrm{ns}}$ & $0.227 *$ & $1.946^{\text {n.s }}$ & $36.180^{\text {n.s }}$ \\
\hline $\mathrm{T} 3-5.0 \%$ & $128.908^{\mathrm{ns}}$ & $88.700^{\text {ns }}$ & $38.558^{\mathrm{ns}}$ & $7.712^{\mathrm{ns}}$ & $32.497^{\mathrm{ns}}$ & $0.223 *$ & $2.058^{\mathrm{n} . \mathrm{s}}$ & $36.380^{\text {n.s }}$ \\
\hline $\mathrm{T} 4-7.5 \%$ & $130.908^{\mathrm{ns}}$ & $84.850^{\mathrm{ns}}$ & $40.547^{\mathrm{ns}}$ & $8.108^{\mathrm{ns}}$ & $37.950^{\mathrm{ns}}$ & $0.217^{*}$ & $2.392 *$ & $38.710^{\text {n.s }}$ \\
\hline $\mathrm{T} 5-10 \%$ & $133.767^{\mathrm{ns}}$ & $91.133^{\mathrm{ns}}$ & $33.400^{*}$ & $6.680^{*}$ & $35.953^{\text {ns }}$ & $0.197 *$ & $2.133^{*}$ & $35.300^{\text {n.s }}$ \\
\hline LSD & 35.254 & 12.812 & 13.685 & 2.737 & 28.167 & 0.0695 & 0.219 & 5.805 \\
\hline CV $(\%)$ & 18.255 & 10.027 & 21.917 & 21.917 & 53.299 & 19.748 & 7.250 & 10.513 \\
\hline
\end{tabular}

LSD: least significant difference. ${ }^{\text {ns: }}$ not significant at the level of $5 \%$ probability by Dunnett's test; * significant at the level of 5\% probability by Dunnett's test. CV: coefficient of variation.

Total cholesterol was altered with the inclusion of MWM in the diets, such that the broilers fed diets with $7.5 \%$ and $10.0 \%$ MWM displayed increases in this variable of $4.2 \%$ and $6.5 \%$, respectively. These 
elevations might have been caused by the $6.0 \%$ and $13.8 \%$ increased levels of HDL-C corresponding to the $7.5 \%$ and $10.0 \%$ inclusion rates of MWM, respectively.

The amounts of TAG, VLDL-C and LDL-C did not vary among treatments except for the MWM level of $7.5 \%$ in the diets for broilers at 28 days of age, in which the values were lower. Yet, at $10.0 \%$ inclusion of MWM, there was an increase in the above-mentioned variables, possibly as a result of the increased levels of soybean oil, as the MWM levels were elevated to make the diets isocaloric. Thus, the substitutions of the diets in the final phase elevated the level of soybean oil in the diet with the addition of $10 \% \mathrm{MWM}$ from $4.52 \%$ to $5.82 \%$, corresponding to a $4.93 \%$ higher value compared with birds receiving the control diet in the starter phase.

Some studies have associated reductions in the levels of triacylglycerols, VLDL-C and LDL-C and increases in HDL-C levels with the presence of unsaturated fatty acids (UFA) in diets. Vegetable oils are usually rich in UFA, among which the omega-6 UFA are the most abundant. Mango waste meal is rich in oleic and linoleic UFA (FOWOMOLA, 2010). Abdalla et al. (2007) found $46.1 \%$ oleic, $8.2 \%$ linoleic and $1.2 \%$ linoleic acids in the meal of the seed of Egyptian mango, with an unsaturated/ saturated fatty acid ratio of 1.3 for total lipids, wherein the largest proportion of the UFA was in the form of phospholipids. Solís-Fuentes and Durán-deBazúa (2004) found 40.81\% oleic, 6.06\% linoleic and $0.64 \%$ linolenic acids in a Mexican mango variety. Vieira et al. (2009) detected a concentration of $52.71 \%$ of UFA in a meal of peels, seeds and seed almond of Mangifera indica $L$. variety Ubá.

Celebi and Utlu (2006) studied several sources of lipids and found that diets rich in linoleic and oleic acids were capable of reducing VLDL-C and LDL-C concentrations, which also occurred in the present study. Silva et al. (2012) reported that in lipid metabolism, omega-3 fatty acids cause reductions in serum triglycerides via reduction of the synthesis of VLDL and apolipoprotein B and increases in HDL and LDL; however, such alterations depend on the basal values and on the levels of UFA in the diet. Grundy (1987) compared oleic and linoleic acids in their capacity to decrease cholesterol and concluded that oleic acid reduced LDL-C levels without affecting HDL-C, but linoleic acid reduced both LDL-C and HDL-C. The results observed in the current experiment were similar, with no significant alterations detected in the HDL-C levels for any of the tested levels at all ages, although they displayed higher values than control.

Another noteworthy aspect of mango waste is the presence of vitamins $\mathrm{A}$ and $\mathrm{C}$ and the phenolic compounds that act as antioxidants (RIBEIRO et al., 2007). The variety Ubá utilized in this study contains much higher amounts of polyphenols and vitamin $\mathrm{C}$ and antioxidant powers in the peel, seed and pulp (RIBEIRO et al., 2008). This fact may have been the reason for the reducing effect on lipoproteins observed in the present study, because these compounds protected the unsaturated fatty acids from both the meal itself and from the soybean oil added to the diets.

\section{Conclusions}

At 14, 28 and 42 days of age, the VLDL-C, LDL-C and total TAG contents were found to decrease with the mango waste meal inclusion levels of $5.0 \%$ and $7.5 \%$ in the diets, which may be considered an indicator of improvement in the metabolic conditions of broilers.

\section{Ethics and Biosafety Committee}

Request $n^{\circ} .: 08 / 2014$ approved by the Ethics Committee on the Use of Livestock Animals of Universidade Federal de Viçosa. 


\section{Acknowledgments}

To Fundação de Amparo à Pesquisa do Estado de Minas Gerais (FAPEMIG), Coordenação de Aperfeiçoamento de Pessoal de Nível Superior (CAPES) and Conselho Nacional de Desenvolvimento Cientifico e Tecnológico (CNPq) for financing the project. To the juice industry Goody ${ }^{\circledR}$ for providing the mango waste.

\section{References}

ABDALLA, A. E. M.;DARWISH, S. M.;AYAD, E. H. E.; EL-HAMAHMY, R. M. Egyptian mango by-product 2: antioxidant and antimicrobial activities of extract and oil from mango seed kernel. Food Chemistry, Oxon, v. 103, n. 4, p. 1141-1152, 2007.

AJILA, C. M.; NAIDU, K. A.; BHAT, S. G.; RAO, U. J. S. P. Bioactive compounds and antioxidant potential of mango peel extract. Food Chemistry, Oxon, v. 105, n. 3, p. 982-988, 2007.

CELEBI, S.; UTLU, N. Influence of animal and vegetable oil in layer diets on performance and serum lipid profile. International Journal of Poultry Science, Pakistan, v. 5, n. 4, p. 370-373, 2006.

FOWOMOLA, M. A. Some nutrients and antinutrients contents of mango (Magnifera indica) seed. African Journal of Food Science, AsokoroIsland Abuja, v. 4, n. 8, p. 472-476, 2010.

FREITAS, E. D.;BORGES, A. G.; TREVISAN, M. T. S.; WATANABE, P. H.; CUNHA, A. L.; PEREIRA, A. L. F.; ABREU, V. K.; NASCIMENTO, G. A. J. Extratos etanólicos da manga como antioxidantes para frangos de corte. Pesquisa Agropecuária Brasileira, Brasília, v. 47, n. 8, p. 1025-1030, 2012.

GERON, L. J. V.; TRAUTMANN-MACHADO, R. J.; MOURA, D. C.; MARQUES, F. M.; SOUZA, O. M.; PAULA, E. J. H. Caju, canola, cevada, cupuaçu e seus resíduos utilizados na nutrição de ruminantes. PUBVET, Londrina, v. 7, n. 12, ed. 235, art. 1549, p. 1-44, 2013.

GONZÁLEZ, F. H. D.; HAIDA, K. S.; MAHL, D.; GIANNESI, G.; KRONBAUER, E. Incidência de doenças metabólicas em frangos de corte e uso do perfil bioquímico sangüíneo para o seu estudo. Revista Brasileira de Ciência Avícola, Campinas, v. 3, n. 2, p. 141-147, 2001.

GRUNDY, S. M. Monounsaturated fatty acids, plasma cholesterol, andcoronaryheartdisease. American Journal of Clinical Nutrition, Bethesda, v. 45, n. 5, p. 1168-1175, 1987.
HASEGAWA, M. Y.; FONTEQUE, J. H.;KOHAYAGAWA, A.; BORETTI, L. P. Avaliação do perfil eletroforético das proteínas séricas em matrizes pesadas (Gallus Gallus Domesticus) da linhagem Avian Farm. Revista Brasileira de Ciência Avícola, Campinas, v. 4, n. 3, p. 203-207, 2002.

HUBER, K.; QUEIROZ, J. H.; MOREIRA, A. V. B.; RIBEIRO, S. M. R. Caracterização química do resíduo agroindustrial da manga Ubá (Mangifera indica L.): uma perspectiva para a obtenção de antioxidantes naturais. Revista Brasileira de Tecnologia Agroindustrial, Curitiba, v. 6, n. 1, p. 640-652, 2012.

MACARI, M.; LUQUETTI, B. C. Fisiologia cardiovascular. In: MACARI, M. Fisiologia aviária aplicada a frangos de corte. Jaboticabal: FUNEP/ UNESP, 2002. p. 17-35.

PONSO, R.; FARIA, D. E.; ALBUQUERQUE, R.; PAZ,I. C. L.; ARTONI, S. M. B.; SANTOS, A. L.; SAVIANI, G.; ARAÚJO, C. M. M. Avaliação do desenvolvimento da discondroplasia tibial em frangos de corte submetidos à dieta com 25-hidroxicolecalciferol. Brazilian Journal of Veterinary Research and Animal Science, São Paulo, v. 49, n. 2, p. 153-161, 2012.

RAMOS, L. S. N.; LOPES, J. B.; FIGUEIRÊDO, A. V.; FREITAS, A. C.; FARIAS, L. A.; SANTOS, L. S.; SILVA, H. O. Polpa de caju em rações para frangos de corte na fase final: desempenho e características de carcaça. Revista Brasileira de Zootecnia, Viçosa, MG, v. 35, n. 3, p. 804-810, 2006.

RIBEIRO, S. M. R.; BARBOSA, L. C. A.; QUEIROZ, J. H.; KNÖDLER, M.; SCHIEBER, A. Phenolic compounds and antioxidant capacity of Brazilian mango (Mangifera indica L.) varieties. Food Chemistry, Oxon, v. 110, n. 3, p. 620-626, 2008.

RIBEIRO, S. M. R.; QUEIROZ, J. H.; QUEIROZ, M. E. L. R.; CAMPOS, F. M.; SANT'ANNA, H. M. P. Antioxidant in mango(Mangifera indica L.). Pulp. Plant Foods for Human Nutrition, Irapuato, v. 62, n. 1, p. 13$17,2007$.

ROSTAGNO, H. S.; ALBINO, L. F. T.; DONZELE, J. L.; GOMES, P. C.; OLIVEIRA, R. F.; LOPES, D. C.; FERREIRA, A. S.; BARRETO, S. L. T. Tabelas brasileiras para aves e suínos: composição de alimentos e exigências nutricionais. 2. ed. Viçosa, MG: UFV/DZO, 2005. 186p.

SILVA, J. E. S.; MOURA, A. M. A.; NOGUEIRA, R. A. Efeito dos ácidos graxos essenciais sobre lipidemia e vascularização da membrana vitelina de codornas japonesas. Arquivo Brasileiro de Medicina Veterinária e Zootecnia, Belo Horizonte, v. 64, n. 6, p. 1603-1612, 2012. 
SOLÍS-FUENTES, J. A.; DURÁN-DE-BAZÚA, M. C. Mango seed uses: thermal behavior of mango seed almond fat and its mixtures with cocoa butter. Bioresource Technology, Trivandrum, v. 92, n. 1, p. 71-78, 2004.

SQUIRES, E. J.; SUMMERS, J. D. A consideration of comparative metabolic aspects of the aetiology of sudden death syndrome and ascites in broilers. British Veterinary Journal, Amsterdam, v. 149, n. 3, p. 285-294, 1993.

STATISTICAL ANALYSIS SYSTEM - SAS. SAS System for Windows. Release 8. 2. Cary: SAS Institute, 2001.

TOGASHI, C. K.; FONSECA, J. B.; SOARES, R. T. R. N.; COSTA, A. P. D.; FERREIRA, C. S.; DETMANN, E. Utilização de alho e cobre na alimentação de frangos de corte. Revista Brasileira de Zootecnia, Viçosa, MG, v. 37, n. 6, p. 1036-1041, 2008.
VIEIRA, P. A. F.; QUEIROZ, J. H.; VIEIRA, B. C.; MENDES, F. Q.; BARBOSA, A. A.; MÜLLER, E. S.; SANT'ANA, R. C.; MORAES, G. H. K. Caracterização química do resíduo do processamento agroindustrial da manga (Mangifera indica L.) var. Ubá. Alimentos e Nutrição, Araraquara, v. 20, n. 4, p. 617-623, 2009.

VIEIRA, P. A. F.; QUEIROZ, J. H.; ALBINO, L. F. T.; MORAES, G. H. K.; BARBOSA, A. A.; MÜLLER, E. S.; VIANA, M. T. S. Efeitos da inclusão de farelo do resíduo de manga no desempenho de frangos de corte de 1 a 42 dias. Revista Brasileira de Zootecnia, Viçosa, MG, v. 37, n. 12, p. 2173-2178, 2008.

VIEITES, F. M.; NALON, R. P.; SANTOS, A. L.; BRANCO, P. A. C.; SOUZA, C. S.; NUNES, R. V.; CALDERANO, A. A.; ARRUDA, N. V. Desempenho, rendimento de carcaça e cortes nobres de frangos de corte alimentados com rações suplementadas com Solanum glaucophyllum. Semina: Ciências Agrárias, Londrina, v. 35, n. 3, p. 1617-1626, 2014. 